DOI 10.32726/2411-3417-2019-3-25-33

УДК $341 ; 342 ; 327 ; 93$

\title{
ЭЛИЗЕО БЕРТОЛАЗИ
}

\section{Италия - Крым: история и современность}

Аннотация. 18 мая 2016 г. в Венеции Совет региона Венето первым в Европейском союзе признал воссоединение Крыма с Россией. Эта резолючия проложила путь к аналогичным действиям других итальянских региональных учреждений: 29 июня 2016 г. в Генуе Совет региона Лигурии утвердил признание Крыма, 5 июля настала очередь регионального совета Ломбардии. Венето и Лигурия неслучайно пошли на этот шаг, для этого имеются вполне конкретные исторические причины - в Крыму в средние века успешно существовали венецианские и генуэзские колонии.

Ключевые слова: Крым, Венето, Лигурия, венецианские колонии, генуэзские колонии, партия «Лига» (Лига Севера).

$\mathrm{B}^{\mathrm{n}}$ последние годы Крым оказался в центре международного внимания. Политический кризис на Украине в 2014 г. привел к тому, что Крым вошел в состав России. Это вызвало конфликт между Москвой и Западом, который не признает законность крымского референдума. Конфликт в некоторых аспектах напоминает сценарий Крымской войны, когда в середине XIX в. царская Россия противостояла беспрецедентному союзу между Османской империей, Великобританией, Францией и Королевством Сардиния. Сегодня постсоветская Россия противостоит Соединенным Штатам, Европейскому союзу и НАТО в неразрешимом, казалось бы, конфликте, в котором ни одна из вовлеченных сторон пока не добилась окончательной победы.

Напряженная ситуация вокруг Крыма, как и в прошлом, объясняется фундаментально значимым местом, которое он занимает между Средиземноморьем и Евразией.

В течение долгой и неспокойной истории полуострова его заселяли многие народы: таурийцы, киммерийцы, скифы, греки, готы, датчане, византийцы, евреи, армяне, генуэзцы, венецианцы, татары и русские. Ни один из них окончательно так и не связал свое имя с Крымом, но все они оставили здесь важные исторические свидетельства своего пребывания. Крым похож на сложную мозаику, одни элементы которой постоянно заменялись другими. Культурная неоднородность, пожалуй, является его фундаментальной характерной чертой.

Сведения об авторе: БЕРТОЛАЗИ Элизео - эксперт Института высших геополитических исследований и смежных наук (Рим, Италия) (IsAG), учредитель ассочиации «Венето - Россия», почетный член ассочиачии «Ломбардия - Россия», доктор философии по культурной антропологии (Италия), ebertolasi@mail.ru. 
C начала XIII в. генуэзцы и венецианцы, воспользовавшись окончательным распадом Византийской империи после падения Константинополя в 1204 г., стали создавать свои колонии на Черноморском побережье, включая Крым, продолжая и в этом регионе свое взаимное политическое и торговое соперничество [Ferrari, Pupulin]. Обе морские республики, Венеция и Генуя, основали здесь поселения: Чембало (Балаклава), Лупико (Алупка), Солдая (Судак), Черкио (Керчь) и, конечно, Каффу (Феодосия), которая стала главным городским центром региона. Несмотря на немноголюдность, эти поселения были весьма активны.

Доминировали в Крыму генуэзцы. Около двух веков они главенствовали в политической и экономической жизни прибрежных городов, население которых всегда отличалось многоэтничностью. В этот период генуэзцы наладили отношения как с восстановленной в 1261 г. Византийской империей, так и с Золотой Ордой, которая около середины XIII в. возникла как автономное государство в самой западной части монгольской империи. Генуэзцы, греки и армяне жили бок о бок в прибрежных городах Крыма, поддерживая выгодное, хотя и непростое, сотрудничество с татарами, доминировавшими в северной части полуострова.

Говоря о присутствии итальянцев в Крыму в последующие столетия, к венецианцам и генуэзцам следует добавить еще и представителей юга Италии.

С научной точки зрения приморско-сельская община итальянцев Крыма изучалась в 1930-х годах советским лингвистом и этнографом Владимиром Федоровичем Шишмарёвым в рамках более широкого исследования, которое охватывало романские меньшинства в СССР, имевшиеся на Юге Украины, Понтийском побережье и Северном Кавказе. Его работы на эту тему были собраны и опубликованы в 1975 г. в книге «Романские поселения на юге России» [Шишмарев], в которой анализировались влахские, французские и итальянские группы.

Основная часть труда этнографа посвящена семьям, эмигрировавшим из итальянской области Апулия в 1870-е годы. (В миграционном притоке итальянцев в Крым выделяются два периода: 1780 - 1830 гг. и после 1870 г.) Уклад жизни этих моряков описан так: они почти всегда владели огородом и домом, «который не отличается от домов других полусельских жителей Керчи». Выделялись же они манерой одеваться, а также кулинарными пристрастиями и устным народным творчеством.

Хотя В. Шишмарёв изучал историю иммиграции этой группы, его исследования в основном носили диалектологический характер. То, что привлекло советского лингвиста на побережье Крыма, на самом деле было «остатками» диалекта южной Италии. В докладах, написанных во время полевых работ в 1930-х годах, Шишмарёв описывал диалект апулийской общины Керчи, смешанный с русским языком.

Обратимся теперь к венецианскому присутствию в Крыму, представление о котором крайне важно для поинмания особых отношений между регионом Венето (Венеция) и Крымом на современном этапе. 
Наследники древней цивилизации - венецианцы - были великими путешественниками. Светлейшая Республика Венеция, времена которой охватывают 1100 лет (6971797), как известно, достигла весьма высокого уровня развития и благосостояния. При этом венецианцами двигал не только неукротимый дух приключений, но и многовековая традиция торговли, связанная с желанием поднять уровень жизни, обогащая ее красивыми вещами. Для венецианцев Черное море и Крым были не столько «придатком Средиземноморья», сколько «морским мостом в Азию», через который пролегали торговые пути.

В самом деле, еще до XIV столетия венецианцы посещали Тану, расположенную в устье реки Дон в Азовском море. Венецианцы восстановили этот город и обеспечили его развитие. Крым, благодаря своему географическому положению, также всегда играл важную роль в деятельности венецианских торговцев к востоку от Черного моря.

Поэтому не будет преувеличением сказать, что нынешние усилия, предпринимаемые регионом Венето в поддержку Крыма, являются своего рода «возвращением к прошлому», точнее - к той земле, где когда-то широко присутствовали предки жителей этого итальянского региона.

К сожалению, правительство Италии продолжает поддерживать режим санкций против России, введенных Европейским союзом и США, которые относятся к Италии как к колонии. Италия уже потеряла порядка 7 млрд евро из-за безрассудной политики антироссийских санкций. В ситуации тяжелого экономического кризиса (который поразил Италию в последние годы) санкции против Москвы стали для итальянской экономики фактически самоубийством.

18 мая 2016 г. Совет региона Венето первым в Европейском союзе официально признал Крым частью России [Consiglio regionale...]. Соответствующая резолюция была принята вопреки позиции ЕС и Запада в целом. Между тем Евросоюз считал и продолжает считать крымский референдум незаконным и вводит все новые санкции против России. Со стороны Венето нужна была большая смелость, чтобы принять альтернативное решение. Инициатором этого акта стал депутат Совета региона Венето Стефано Вальдегамбери.

Принятая Советом региона Венето резолюция обязывала председателя Совета Роберто Чамбетти обратиться к правительству и национальному парламенту Италии, а также к брюссельским инстанциям с предложением заново рассмотреть отношения Европейского союза с Российской Федерацией и последствия антироссийских санкций, которые не только наносят ущерб экономике, но и отрицательно влияют на международную безопасность.

Несмотря на символический характер венетийской резолюции, она вызвала настоящую бурю. Сразу же последовала реакция посла Украины в Италии, который направил открытое письмо депутатам Совета Венето, выразив свое разочарование [Lettera aperta....]. В письме украинский посол предлагал региональным депутатам отказаться 
от своей инициативы, что по сути являлось недопустимым вмешательством иностранного представительства в вопросы, связанные с политическим выбором Италии.

Об этом свидетельствовал и Риккардо Барбисан, заместитель главы партийной фракции «Лиги Севера» в Совете Венето: «В письме нас просили не проводить голосование. Мы восприняли это как попытку нас запугать, но она не имела желаемого эффекта... Если они совершают действия такого рода, это говорит об их уверенности в том, что у них есть влиятельные защитники. Но мы не сгибаемся. Мы уважаем принципы ООН, относящиеся к самоопределению народов. Мы считаем, что те, кто говорят по-русски, думают по-русски, едят по-русски, хотят расплачиваться рублем, могут свободно проводить референдум о том, какой международный статус им выбрать вместо того, чтобы оставаться в государстве, где их специфика не уважается. Это основополагающий принцип» [Santi No sanzioni....].

Возникает вопрос: каковы же причины принятия Советом Венето этой резолюции? По моему мнению, тут есть два определяющих фактора.

Безусловно, это решение связано с большими экономическими потерями из-за режима санкций в отношении России. Санкции обернулись настоящей катастрофой для экономики Венето, для экспорта в Россию, особенно в мебельном и агропродовольственном секторах.

Однако есть и другой фактор, который следует учитывать. Совет региона Венето занял такую позицию, потому что ему близко желание народа Крыма получить независимость от Украины. Венецианский народ тоже давно стремится к автономии или даже независимости от Итальянской Республики. 22 октября 2017 г. в Венето прошел референдум по вопросу об автономии. Результат оказался ошеломляющим, с очевидной победой тех, кто «за» более широкую автономию - 98\% при явке 57,2\% [См.: Referendum sull'autonomia...].

Причем в регионе Венето (7 провинций) на тот момент проживало 4068560 человек, имеющих право голоса, однако правительство Италии потребовало внести в списки около 330000 венецианцев, проживающих за границей, что увеличивало списочный состав избирателей на 8,11\%. Для инициаторов референдума это стало очевидно неблагоприятным условием, учитывая низкую вероятность того, что проживающие за границей венетийцы смогут приехать в Венето для голосования. Тем не менее даже в этих обстоятельствах явка в регионе Венето заметно превысила кворум, требуемый для действительности референдума $(50 \%+1 \text { человек })^{1}$.

Для Венето эта победа автономистов имела очевидную историческую значимость. Выбранная дата голосования имела важный символический смысл: 22 октября 1866 г.

1 В отличие от Ломбардии, где в тот же день проводился аналогичный референдум и где явка не превысила 40\%. - Прим. ред. [См.: Referendum sull'autonomia...] 
Италия в результате спорного плебисцита аннексировала Венето (см. прим. ред. ${ }^{1}$ ). В 2017 г., 151 год спустя, жители Венето громко заявили о своем желании вернуть себе автономию. И в настоящее время, благодаря тому, что в состав итальянского правительства входят представители партии «Лига» Маттео Сальвини, уже определяются параметры этой автономии.

Инициативы, реализуемые регионом Венето в отношении Крыма, не исчерпываются признанием полуострова частью России. 14-16 октября 2016 г. в Крыму побывала большая делегация, состоявшая из региональных советников от различных регионов Италии - Венето, Ломбардии, Лигурии, Тосканы и Эмилии-Романьи, - а также представителей итальянского бизнес-сообщества [Delegazione di consiglieri...]. Возглавили делегацию президент Совета Венето Р. Чамбетти и региональный депутат Венето С. Вальдегамбери.

Важнейший эффект признания Крыма частью России регионом Венето состоит в том, что этот факт послужил примером для других итальянских регионов. Вторым регионом страны, который последовал за Венето, не случайно стала Лигурия - область, территория которой некогда управлялась Генуэзской Республикой. Венеция и Генуя, имевшие в Средние века свои колонии на Крымском полуострове, ныне объединились в признании крымского референдума 2014 г.

По инициативе регионального лидера Лиги Севера Алессандро Пиана, региональный Совет Лигурии в Генуе 29 июня 2016 г. практически единогласно высказался против санкций в отношении России, и признал право Крыма на самоопределение [Approvata...]. (Принятая резолюция предполагала также создание «Комитета против санкций в отношении $Р Ф$, за признание права населения Крыма на самоопределение и в защиту традиционной продукции Лигурии» [lbid]. - Прим. ред.).

Эдоардо Рикси, советник по вопросам экономического развития и секретарь Лиги Севера в Лигурии, подчеркнул, что решение регионального Совета мотивировано не только стремлением добиться снятия санкций, наносящих ущерб лигурийским производителям, но и «историческими отношениями между Генуей и Крымом» [Santi Via sanzioni...].

Через несколько дней, 5 июля 2016 г., настала очередь Ломбардии. Региональный Совет в Милане также проголосовал за предложение Лиги Севера признать Крым частью России и требовать отмены антироссийских санкций [Bertolasi Una nuova...].

1 Передача Венеции возникшему в 1861 г. Итальянскому королевству была согласована европейскими державами в ходе дипломатической подготовки к австро-прусско-итальянской войне 1866 г., в секретном договоре (апрель 1866 г.) между бисмарковской Пруссией и Итальянским королевством при поддержке Франции, в качестве компенсации за участие Италии в военных действиях против Австрии. Плебисцит в Венеции 21-22 октября 1866 г. одобрил присоединение к Италии почти единогласно, но условия его проведения и убедительность официальных результатов критикуются рядом историков. - Прим. ред. 
Следует отметить, что лидер Лиги (до 2018 г. - Лига Севера) М. Сальвини еще до того, как стать вице-премьером и министром внутренних дел Италии, не скрывал своих симпатий к России и Крыму. В июле 2018 г. в интервью Washington Post он заявил, что считает Крым частью России [См.: Italy has done a lot... Matteo Salvini...]. За этим предсказуемо последовала истерическая реакция Киева. Посла Италии вызвали в украинский МИД, чтобы выразить протест [Коментар МЗС України...]. Ранее, в октябре 2014 г., когда М. Сальвини был только лидером партии Лига Севера, он к неудовольствию Киева посетил Крым. Более того, Сальвини квалифицировал демонстрации, которые в начале 2014 г. привели к смене власти на Украине, как «фальшивую революцию»'.

25 октября 2018 г. в знаменитом Ливадийском дворце в Ялте к созданной за год до этого международной ассоциации «Друзья Крыма» присоединилось 36 стран. На встрече, в частности, присутствовали представители Италии, Армении, Австрии, Болгарии, Китая, Германии, Греции, Израиля, Японии, Норвегии, Словакии, Туниса и Турции. Президентом Ассоциации был избран словацкий политик Ян Чарногурский (премьер-министр Словацкой Федеративной Республики с мая 1991 г. по июнь 1992 г., до распада Чехословакии). В числе присоединившихся к ассоциации «Друзья Крыма» со стороны Италии находился региональный депутат Венето С. Вальдегамбери [Бывший премьер-министр...].

Партнером ассоциации «Друзья Крыма» будет ассоциация «Венето - Россия». Цель таких ассоциаций в настоящее время состоит в содействии деятельности СМИ и других структур, направленной на информирование общественности о серьезных нарушениях основных прав человека по отношению к крымскому народу, вызванных жесткими санкциями, введенными США и Европейским союзом.

Не только делегации политических деятелей, но и предприниматели Венето неоднократно посещали и продолжают посещать Крым. В ходе одного из таких визитов по случаю участия в VIII международном аграрном форуме «АгроЭкспоКрым», состоявшемся в Ялте 15-17 февраля 2018 г., президент ассоциации «Венето - Россия» Пальмарино Дзоккателли подписал меморандум о сотрудничестве с генеральным директором выставочной компании «ЭкспоКрым» Сергеем Семерецким [Bertolasi Veneto...].

По словам П. Дзоккателли, «в настоящее время приоритетным является адаптация как можно большего количества компаний Венето к социально-экономическим реалиям Крыма для того, чтобы они могли внести значимый в инновационно-технологическом плане вклад в проекты развития этой прекрасной земли». «В Венето, — отметил он, - мы ощущаем крайне негативный эффект введенных США и ЕС антироссийских

1 В интервью газете «Вашингтон пост» М. Сальвини не согласился с корреспондентом, назвавшим крымский референдум фальшивым. «Был референдум, и 90 процентов людей проголосовали за возвращение Крыма в состав Российской Федерации, - сказал он... Сравните это с фальшивой революцией на Украине, которая была псевдореволюцией, финансируемой иностранными державами - подобно революциям Арабской весны. Существуют исторически русские зоны с русской культурой и традициями, которые на законных основаниях принадлежат Российской Федерации» [Matteo Salvini...] 
санкций, которые нанесли большой ущерб многим нашим фирмам. Возможности Крыма открывают широкие перспективы для расширения и роста нашего бизнеса, чему мы, конечно, очень рады. ... И наш личный опыт показывает, что ситуация совершенно отличается от той, которую рисуют разные СМИ, подконтрольные НАТО и ЕС». На вопрос «Вы не боитесь санкций?» П. Дзокателли ответил: Нет! Есть те, кто угрожает, кто стремится к конфликту с Крымом и с Россией - мы, наоборот, предлагаем дружбу. Мы верим в сотрудничество и создаем рабочие места ... чего нам бояться? Своим примером мы хотим показать, что русским можно доверять» [lbid].

Итальянское правительство также не забывает об итальянцах Крыма. В настоящее время их в Крыму насчитывается более 300 человек, большинство из которых проживают в Керчи, где в 2008 г. была основана Ассоциация «C.E.R.K.I.O.» (Comunità degli Emigrati in Regione di Krimea - Italiani di Origine / Сообщество эмигрантов в Крымском регионе - итальянского происхождения); председателем итальянской общины Крыма является историк Джулия Джаккетти-Бойко [Bertolasi La Giornata....].

После возвращения Крыма в состав России в официальном Указе от 21 апреля 2014 г. о мерах по реабилитации депортированных народов итальянцы, к сожалению, не упоминались [Указ Президента Российской Федерации от 21.04.2014...]. Однако по случаю встречи с С. Берлускони в Ялте в 2015 г. президент В. Путин своим указом обновил список реабилитированных народов, признав итальянскую общину Крыма в качестве депортированного меньшинства [Указ Президента Российской Федерации о мерах...].

В ознаменование трагедии депортации, 27 января 2019 г. в Керчи был отмечен «День памяти итальянских жертв репрессий и депортации». Итальянская община Крыма ежегодно отмечает эту дату с 2009 г. В 2019 г. в мемориальных мероприятиях в Керчи принял участие депутат парламента Италии Вито Коменчини от партии Лига, уже посещавший Крым, и в частности Керчь, в августе 2018 г.

В заключение хотел бы процитировать слова председателя Комиссии Совета Федерации РФ по информационной политике Алексея Пушкова о российско-итальянских отношениях: «Россия исторически поддерживает хорошие отношения с Италией и с ее политическим миром. Еще до того, как появилась “Лига Севера”, у нас уже были хорошие отношения с целым рядом итальянских политиков. Я встречался с Наполитано (бывший президент Италии) и со многими другими, были и остаются прекрасными отношения с Берлускони. Поэтому я не стал бы выделять Сальвини из ряда итальянских политиков, с которыми Россия поддерживает и готова поддерживать хорошие отношения... “Лига Севера” - одна из ведущих политических партий страны, и Сальвини, как мне кажется, завоевал уже довольно большой авторитет не только в самой Италии, но и за ее пределами. Он выглядит как политик нового типа, он обладает решительностью, не боится занимать позицию. Да, он навлекает на себя критику, его атакуют, это так, но это черта лидера. Он имеет и поддержку - и это тоже черта лидера» ${ }^{.}$

1 Интервью А. Пушкова Э. Бертолази (личный архив автора). 


\section{Литература}

Бывший премьер-министр Словакии возглавил совет ассоциации «Друзья Крыма» // РИА Новости. 26.10.2018. — URL: ria.ru/20181026/1531574174.html (дата обращения: 14.06.2019).

Интервью А. Пушкова Э. Бертолази (личный архив автора).

Коментар МЗС України у зв'язку з недружніми висловлюваннями Міністра внутрішніх справ Італії М.Сальвіні щодо України // Міністерство закордонних справ України. 20.07.2018. — URL: $\quad$ mfa.gov.ua/ua/press-center/news/66346-komentar-mzs-ukrajini-u-zvjazku-znedruzhnimi-vislovlyuvannyami-ministra-vnutrishnih-sprav-italiji-msalyvini-shhodo-ukrajini (date of access: 01.04.2019).

Указ Президента Российской Федерации о мерах по реабилитации армянского, болгарского, греческого, итальянского, крымско-татарского и немецкого народов и государственной поддержке их возрождения и развития (В редакции Указа Президента Российской Федерации от 12.09.2015 г. N 458) // Официальный интернет-портал правовой информации. — URL: pravo.gov.ru/proxy/ips/?docbody=\&firstDoc=1\&lastDoc=1\&nd=102349183 (дата обращения: 01.04.2019).

Указ Президента Российской Федерации от 21.04.2014 г. № 2680 мерах по реабилитации армянского, болгарского, греческого, крымско-татарского и немецкого народов и государственной поддержке их возрождения и развития // Крым. История России. - URL: krym. rusarchives.ru/dokumenty/ukaz-prezidenta-rossiyskoy-federacii-o-merah-po-reabilitaciiarmyanskogo-bolgarskogo (дата обращения: 01.04.2019).

Шишмарев В.Ф. Романские поселения на юге России: Научное наследие. Л. 1975.

Approvata all'unanimità la mozione della Lega Nord per l'istituzione in Liguria di una commissione contro le sanzioni // SawonaNews. 29.06.2016. — URL: savonanews.it/2016/06/29/legginotizia/argomenti/politica-2/articolo/approvata-allunanimita-la-mozione-della-lega-nord-perlistituzione-in-liguria-di-una-commissione.html (date of access: 01.04.2019).

Bertolasi E. La “Giornata del ricordo” a Kerch.29 gennaio “42, la deportazione degli italiani di Crimea // Sputnik. 29.01.2019. - URL: it.sputniknews.com/opinioni/201901297181686-giornata-delricordo-deportazione-italiani-crimea/ (date of access: 01.04.2019).

Bertolasi E. Una nuova tappa verso la Russia. Anche la Lombardia riconosce la Crimea // Sputnik. 06.07.2016. - URL: it.sputniknews.com/italia/20160706/3052790/russia-lombardiariconosce-crimea.html (date of access: 01.04.2019).

Bertolasi E. Veneto e Crimea sempre più vicine // Sputnik. 14.03.2018. — URL: it.sputniknews. com/opinioni/201803145770546-Veneto-Crimea-Italia-Russia-vicine/ (date of access: 01.04.2019).

Consiglio regionale. Approvata risoluzione per riconoscimento diritto di autodeterminazione della Crimea // Consiglio regionale del Veneto. 18.05.2016. - URL: consiglioveneto.it/crvportal/ pageContainer.jsp? $n=80 \& p=80 \& c=5 \& e=88 \& t=1$ \&idNotizia=30326 (date of access: 01.04.2019).

Delegazione di consiglieri regionali e imprenditori italiani sfida sanzioni: è in Crimea // Sputnik. 14.10.2016. - URL: it.sputniknews.com/economia/201610143488214-Italia-businesscooperazione-Russia/ (date of access: 01.04.2019).

Ferrari A., Pupulin E. La Crimea, tra Russia Italia e Impero Ottomano. Venezia. 2017.

Italy has done a lot — maybe too much' //The Washington Post. 19.07.2018. — URL: washingtonpost. com/outlook/italy-has-done-a-lot--maybe-too-much/2018/07/19/dc81a292-8acf-11 e8-8aea86e88ae760d8_story.html?noredirect=on (date of access: 01.04.2019).

Lettera aperta dell'Ambasciatore ucraino in Italia // Sputnik. 20.05.2016. — URL: it.sputniknews. 
com/mondo/201605202721345-lettera-aperta-ambasciatore-ucraino-italia/ (date of access: 01.04.2019).

Matteo Salvini riconosce la Crimea come russa: irritazione di Kiev // La prima pagina. 22.07.2018. — URL: laprimapagina.it/2018/07/22/matteo-salvini-riconosce-la-crimea-come-russairritazione-di-kiev/ (date of access: 01.04.2019).

Referendum sull'autonomia del Lombardia // Regione del Lombardia. — URL: regione.lombardia. it/wps/portal/istituzionale/HP/istituzione/autonomia-della-lombardia/referendum-autonomia (date of access: 01.04.2019).

Santi T. No sanzioni, sì Crimea. Il voto veneto è solo l'inizio? // Sputnik. 20.05.2016. — URL: it.sputniknews.com/opinioni/201605202721672-veneto-voto-sanzioni-crimea/ (date of access: 01.04.2019).

Santi T. Via sanzioni alla Russia, anche la Liguria si fa sentire // Sputnik. 12.06.2016. — URL: it.sputniknews.com/italia/201606122876953-via-sanzioni-liguria-si-fa-sentire/ (date of access: 01.04.2019). 